\title{
Aliidiomarina taiwanensis gen. nov., sp. nov., isolated from shallow coastal water
}

Correspondence
Wung Yang Shieh
winyang@ntu.edu.tw

Halophilic, aerobic, Gram-negative, rod-shaped bacteria belonging to the family Idiomarinaceae (Ivanova et al., 2004; Jean et al., 2006), order Alteromonadales (Bowman \& McMeekin, 2005), class Gammaproteobacteria, are unusual in that they contain high levels of iso-branched cellular fatty acids (Ivanova et al., 2004). They can also be distinguished from other members of the order Alteromonadales by their poor ability to use carbohydrates as sole carbon and energy sources (Ivanova et al., 2004). Signature nucleotides in the 16S rRNA gene sequences have been defined for the family Idiomarinaceae, including those at positions $143(\mathrm{C}$ or $\mathrm{A}), 662(\mathrm{~A}), 682(\mathrm{~A}), 830(\mathrm{~T})$ and 856 (A) (Escherichia coli K12 numbering, accession no. AE000471; Jean et al., 2006).

The GenBank/EMBL/DDBJ accession number for the 16S rRNA gene sequence of strain $\mathrm{AlT}^{\top}{ }^{\top}$ is $\mathrm{HO} 537484$.

A supplementary table is available with the online version of this paper.
The family Idiomarinaceae formerly comprised the genera Idiomarina (Ivanova et al., 2004) and Pseudidiomarina (Jean et al., 2006). However, the species of Pseudidiomarina were recently reassigned to the genus Idiomarina (Taborda et al., 2009) because of the difficulty in differentiating the two genera by phenotypic characteristics. At the time of writing, the genus Idiomarina accommodated 16 species, Idiomarina abyssalis (Ivanova et al., 2000), I. baltica (Brettar et al., 2003), I. fontislapidosi (Martínez-Cánovas et al., 2004), I. loihiensis (Donachie et al., 2003), I. ramblicola (Martínez-Cánovas et al., 2004), I. seosinensis (Choi \& Cho, 2005), I. zobellii (Ivanova et al., 2000), I. insulisalsae, I. taiwanensis, I. homiensis, I. marina, I. salinarum, I. sediminum and I. tainanensis (Taborda et al., 2009), and I. donghaiensis and I. maritima (Wu et al. (2009); the latter eight formerly belonged to the genus Pseudidiomarina. Members of the genus Idiomarina have been isolated from saline habitats with a wide range of salinity, such as coastal and oceanic waters, coastal 
sediments, inland hypersaline wetlands, solar salterns and submarine hydrothermal fluids.

During a survey of diversity of heterotrophic marine bacteria, strain $\mathrm{AITl}^{\mathrm{T}}$ was recovered from a seawater sample collected from the shallow coastal region of Bitou Harbour, New Taipei, on the north coast of Taiwan. The sample was diluted 10 -fold with sterile $\mathrm{NaCl} /$ Tris buffer $(30 \mathrm{~g} \mathrm{NaCl}$ and $0.24 \mathrm{~g}$ Tris base, $1 \mathrm{l}$ deionized water; $\mathrm{pH}$ 8.0). Aliquots $(0.1 \mathrm{ml})$ of dilutions $\left(10^{-1}\right.$ to $\left.10^{-3}\right)$ were spread on polypeptone-yeast (PY) agar (Shieh et al., 2000) in triplicate and incubated at $30{ }^{\circ} \mathrm{C}$ in the dark for 7 days under aerobic conditions. Individual colonies were picked and purified by successive streaking on PY agar. The isolate was maintained at $25{ }^{\circ} \mathrm{C}$ in PY stab cultures under aerobic conditions.

Morphological and physiological characterization was carried out following established procedures (Jean et al., 2006). Analysis of cellular fatty acids, isoprenoid quinones and DNA G $+\mathrm{C}$ content was carried out using early stationary-phase cells harvested from cultures grown in PY broth or on PY agar at $30{ }^{\circ} \mathrm{C}$ for 3 days under aerobic conditions, according to the methods described by Shieh et al. (2008). The HPLC apparatus used for analysis of isoprenoid quinones was equipped with an Inertsil ODS-2 column $(1.5 \times 250 \mathrm{~mm}$; GL Science $)$. Fatty acids were extracted, saponified, esterified and analysed by GC according to the MIDI system (Sasser, 1990) and were identified using the library 2005 supplied in the software package Sherlock Microbial Identification System version 6.0 (MIDI). Polar lipids were analysed using cells grown in marine agar 2216 (Difco) at $30{ }^{\circ} \mathrm{C}$ for 3 days under aerobic conditions, according to the methods described by Lin \& Shieh (2006). Cluster analysis with the software PC-ORD version 5.1 (McCune \& Mefford, 1999) assessed the similarity of the cellular fatty acids of strain $\mathrm{AIT}^{\mathrm{T}}$ and members of the genus Idiomarina. Distances were evaluated using the correlation coefficient and clustering was performed using hierarchical agglomerative clustering with group-average linkage (McCune \& Mefford, 1999).

For analysis of the 16S rRNA gene sequence, cells were grown in PY broth at $30{ }^{\circ} \mathrm{C}$ for 3 days and harvested by centrifugation. Extraction and purification of total genomic DNA and PCR amplification of the 16S rRNA gene were performed according to the methods described by Jean et al. (2006). Sequencing, alignment and comparison with reference sequences available in GenBank, calculation of distance matrices and reconstruction of neighbourjoining, maximum-parsimony and maximum-likelihood trees were performed as described by Shieh et al. (2004) and Jean et al. (2006). The stability of clusters was evaluated by bootstrap analysis of 1000 resamplings.

A nearly complete $16 \mathrm{~S}$ rRNA gene sequence (1441 nt) was determined for strain $\mathrm{AIT}_{1}{ }^{\mathrm{T}}$. Preliminary sequence comparisons with sequences in GenBank indicated that strain $\mathrm{AIT}^{\mathrm{T}}$ belonged to the order Alteromonadales of the class Gammaproteobacteria but that it was not closely related to members of species with validly published names $(<94.0 \%$ $16 \mathrm{~S}$ rRNA gene sequence similarity). The highest sequence similarities (91.5-93.9\%) were observed with the type strains of species in the genus Idiomarina. The distant relationship between strain $\mathrm{AIT1}^{\mathrm{T}}$ and other species was also evident in the neighbour-joining tree (Fig. 1); strain $\mathrm{AIT1}^{\mathrm{T}}$ represented a novel lineage that was an outgroup with respect to the genus Idiomarinaceae, which contained two groups, species clusters I and II. Similar results were also observed in the maximum-parsimony and maximumlikelihood phylogenetic trees (data not shown). It should be noted that the species clusters are based on 16S rRNA gene sequences and no data are available for other phylogenetically useful genes such as groEL, $r p o B$ or $g y r A$. Sequences of strains outside of the family Idiomarinaceae had $<90 \% 16$ S rRNA gene sequence similarity with strain $\mathrm{AIT}^{\mathrm{T}}{ }^{\mathrm{T}}$. On the basis of the phylogenetic analysis using three tree-making algorithms and the low levels of 16S rRNA gene sequence similarity between the isolate and all members of recognized species, strain $\mathrm{AIT}^{\mathrm{T}}$ should be classified as a representative of a novel species in a new genus in the family Idiomarinaceae.

Strain $\operatorname{AIT1}^{\mathrm{T}}$ exhibited the signature nucleotides that are distinctive for the family Idiomarinaceae (Ivanova et al., 2004; Jean et al., 2006): i.e. positions 143 (A), 662 (A), 682 (A), $830(\mathrm{~T})$ and 856 (A) (Table 1). However, the isolate also exhibited nucleotides at positions $240(\mathrm{~A}), 286(\mathrm{~T})$, $762(\mathrm{~A}), 811(\mathrm{~T}), 1336(\mathrm{~A})$ and $1439(\mathrm{G})$ that distinguished it from other members of the family Idiomarinaceae, which exhibited G, C, T, C, C and T/A at these positions, respectively. These nucleotides may be considered as the signature nucleotides of a new genus in the family Idiomarinaceae.

The species clusters I and II in the family Idiomarinaceae also exhibited specific nucleotides: for species cluster I, positions $143(\mathrm{C}), 206(\mathrm{C}), 213(\mathrm{G}), 241(\mathrm{G}), 285(\mathrm{C}), 653$ (A), $658(\mathrm{C}), 748(\mathrm{G})$ and $1439(\mathrm{~T})$; and for species cluster II, positions 1256 (A), 1279 (G), 1286 (A) and 1439 (A) (Table 1). Thus, analysis of species cluster-specific nucleotides, together with the clear phylogenetic divergence of the species clusters and the low 16S rRNA gene sequence similarities between members of the two species clusters (92.7-95.7\%) are consistent with the previous conclusion that species clusters I and II represent the genera Idiomarina and Pseudidiomarina, respectively (Jean et al., 2009). However, members of the genus Pseudidiomarina have recently been reclassified in the genus Idiomarina because of the difficulty in differentiating the two genera based on phenotypic characteristics (Taborda et al., 2009).

The DNA G + C content of strain AIT1 ${ }^{\mathrm{T}}$ was $51.5 \mathrm{~mol} \%$, which was nearly identical to that for I. insulisalsae (51.6\%), but lower than that for I. salinarum CCUG $54359^{\mathrm{T}}$ (53.9 $\mathrm{mol} \%$ ) and higher than those for the remaining members of the genus Idiomarina (45.0-50.4 mol\%) (Table 2). The isolate contained Q-8 as the predominant isoprenoid quinone $(96.3 \%)$ and Q-9 as a minor quinone 


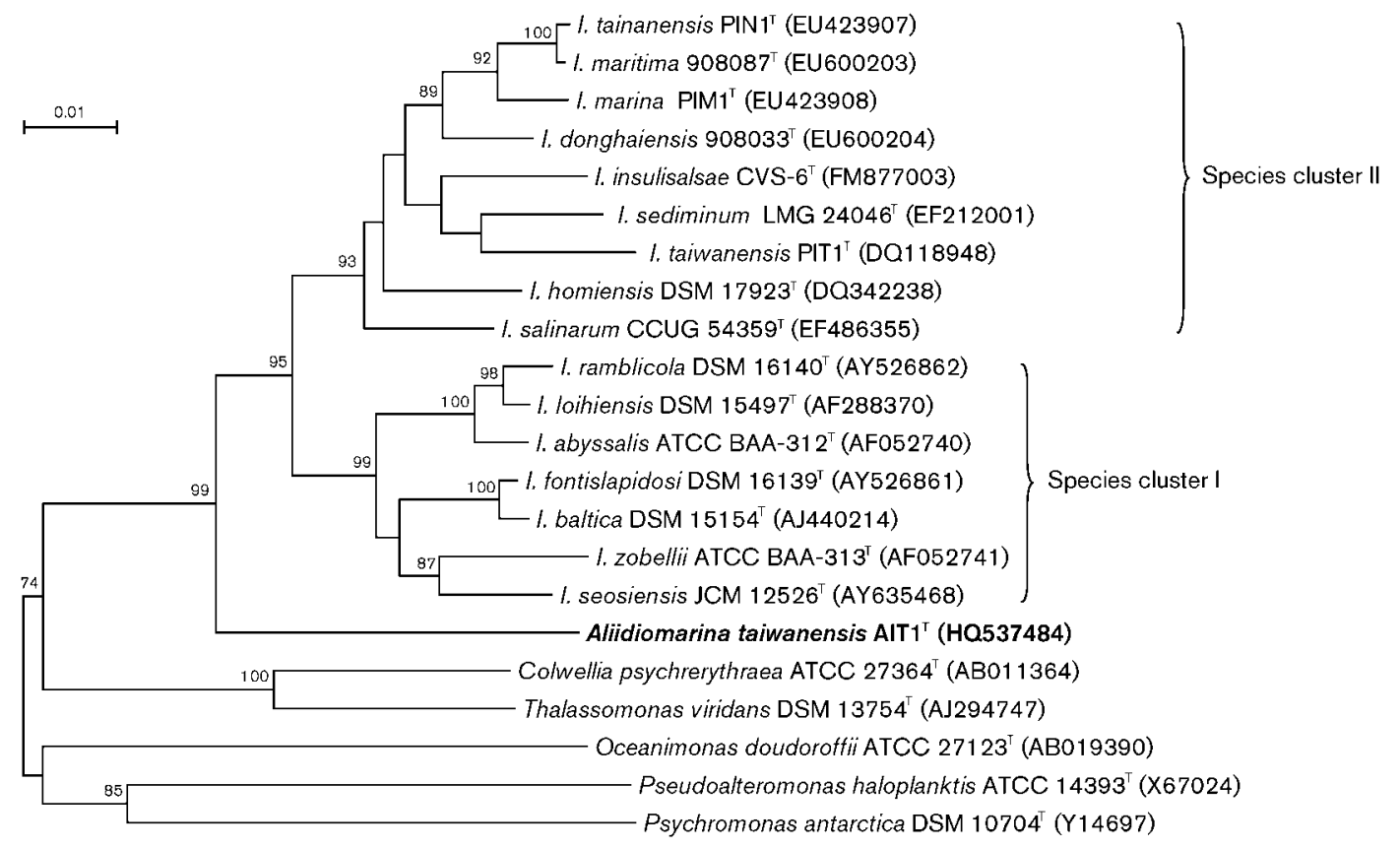

Fig. 1. Unrooted phylogenetic tree derived from neighbour-joining analysis of $16 \mathrm{~S}$ rRNA gene sequences showing the relationship between strain $\mathrm{AIT}^{\top}{ }^{\top}$ and type strains of recognized species of the genus Idiomarina, together with some other related taxa belonging to the Gammaproteobacteria. Bootstrap values ( $>70 \%$ ) based on 1000 replications are shown at branch nodes. Bar, 0.01 substitutions per nucleotide position.

Table 1. Signature nucleotides detected among the 16S rRNA gene sequences of strain $\mathrm{AIT}^{\top}{ }^{\top}$ and species clusters I and II in the genus Idiomarina

Signature nucleotides are shown in bold.

\begin{tabular}{|c|c|c|c|}
\hline \multirow[t]{2}{*}{ Position } & \multicolumn{3}{|c|}{ Nucleotide present in: } \\
\hline & Strain $\mathrm{AIT1}^{\mathrm{T}}$ & Species cluster I & Species cluster II \\
\hline 143 & A & $\mathrm{C}$ & A \\
\hline 206 & $\mathrm{~T}$ & $\mathrm{C}$ & $\mathrm{T}$ \\
\hline 213 & A & G & A \\
\hline 240 & A & G & G \\
\hline 241 & A & G & A \\
\hline 285 & $\mathrm{~T}$ & $\mathrm{C}$ & $\mathrm{T}$ \\
\hline 286 & $\mathbf{T}$ & $\mathrm{C}$ & $\mathrm{C}$ \\
\hline 653 & $\mathrm{C}$ & A & $\mathrm{C}$ \\
\hline 658 & $\mathrm{~T}$ & C & $\mathrm{T}$ \\
\hline 662 & A & A & A \\
\hline 682 & A & A & $\mathrm{A}(\mathrm{T})$ \\
\hline 748 & A & G & A \\
\hline 762 & A & $\mathrm{T}$ & $\mathrm{T}$ \\
\hline 811 & $\mathbf{T}$ & $\mathrm{C}$ & $\mathrm{C}$ \\
\hline 830 & $\mathrm{~T}$ & $\mathrm{~T}$ & $\mathrm{~T}$ \\
\hline 856 & A & A & A \\
\hline 1256 & $\mathrm{C}$ & $\mathrm{C}$ & A \\
\hline 1279 & A & A & G \\
\hline 1286 & $\mathrm{~T}$ & $\mathrm{~T}$ & A \\
\hline 1336 & A & C & $\mathrm{C}$ \\
\hline 1439 & G & $T$ & A \\
\hline
\end{tabular}

(3.7\%). All recognized members of the genus Idiomarina also contain Q-8 as the predominant isoprenoid quinone, but Q-9 has not been previously reported and some members contain Q-7 as the minor quinone (Table 2). The major polar lipids of strain $\mathrm{AIT}^{\mathrm{T}}$ were diphosphatidylglycerol, phosphatidylglycerol and phosphatidylethanolamine, which is typical of the family Idiomarinaceae (Taborda et al., 2009). Strain AIT $1^{\mathrm{T}}$ was similar to other members of the family Idiomarinaceae in that it contained iso- $\mathrm{C}_{17: 0}$, summed feature 9 (comprising iso- $\mathrm{C}_{17: 1} \omega 9 \mathrm{c}$ and/or 10methyl $\mathrm{C}_{16: 0}$ ) and iso- $\mathrm{C}_{15: 0}$ as the major cellular fatty acids (Table 2 and Supplementary Table S1, available in IJSEM Online). However, iso- $\mathrm{C}_{17: 0}$ and summed feature 9 were much more abundant in the isolate than in the reference strains $(52.4 \%$ vs $17.8-36.7 \%)$ and the isolate could also be distinguished by the presence of iso- $\mathrm{C}_{15: 0} 3-\mathrm{OH}$ $(2.2 \%)$, and the absence of iso- $\mathrm{C}_{13: 0}$ and iso- $\mathrm{C}_{13: 0} 3-$ $\mathrm{OH}$. Moreover, cluster analysis of the fatty acids (Fig. 2) differentiated strain $\mathrm{AIT} 1^{\mathrm{T}}$ from all other members of the family Idiomarinaceae. The cluster analysis also divided the family Idiomarinaceae into four groups, one comprising species cluster I (group II) and the others comprising species cluster II (groups I, III and IV).

Strain $\mathrm{AIT}^{\mathrm{T}}$ was mesophilic, halophilic and Gram-negative and produced light brown, circular, convex and nonluminescent colonies on PY agar. Carbohydrate fermentation tests in PY-carbohydrate stab media (Shieh et al., 2000) showed that the isolate did not ferment any of the test carbohydrates (D-arabinose, L-arabinose, cellobiose, dulcitol, 
Table 2. Characteristics useful for differentiating strain $A I T 1^{\top}$ from recognized members of the genus Idiomarina

Strains: 1, Aliidiomarina taiwanensis sp. nov. AIT1 ${ }^{\mathrm{T}}$; 2, I. abyssalis ATCC BAA-312 ${ }^{\mathrm{T}}$; 3, I. baltica DSM $15154^{\mathrm{T}}$; 4, I. fontislapidosi DSM $16139^{\mathrm{T}}$; 5, I. loihiensis DSM $15497^{\mathrm{T}}$; 6, I. ramblicola DSM $16140^{\mathrm{T}}$; 7, I. seosinensis JCM $12526^{\mathrm{T}}$; 8, I. zobellii ATCC BAA-313 ${ }^{\mathrm{T}}$; 9 , I. donghaiensis $908033^{\mathrm{T}}$; 10, I. homiensis DSM $17923^{\mathrm{T}}$; 11 , I. insulisalsae CVS-6 ${ }^{\mathrm{T}}$; 12, I. marina PIM1 ${ }^{\mathrm{T}}$; 13, I. maritima $908087^{\mathrm{T}}$; 14 , I. salinarum CCUG $54359^{\mathrm{T}}$; 15, I. sediminum LMG $24046^{\mathrm{T}}$; 16, I. tainanensis PIN1 ${ }^{\mathrm{T}}$; 17 , I. taiwanensis PIT1 ${ }^{\mathrm{T}}$. Data for columns $2-8,10,11,14$ and 15 were taken from Taborda et al. (2009), for columns 9 and 13 from Wu et al. (2009), for columns 12 and 16 from Jean et al. (2009) and for column 17 from Jean et al. (2006). All strains are positive for oxidase. +, Positive; - , negative/not detected/trace amount detected $(<1 \%)$; ND, no data available.

\begin{tabular}{|c|c|c|c|c|c|c|c|c|c|c|c|c|c|c|c|c|c|}
\hline Characteristic & 1 & 2 & 3 & 4 & 5 & 6 & 7 & 8 & 9 & 10 & 11 & 12 & 13 & 14 & 15 & 16 & 17 \\
\hline Motility & + & + & + & + & + & + & + & + & + & + & + & - & + & ND & - & - & - \\
\hline Monotrichous flagella & + & + & + & + & + & + & + & + & - & + & + & - & + & ND & - & - & - \\
\hline \multicolumn{18}{|l|}{$\mathrm{NaCl}(\%)$} \\
\hline Optimum & $1.5-5.0$ & $3-6$ & $3-6$ & $3-5$ & $7.5-10.0$ & $3-5$ & $7-10$ & $3-6$ & 3 & $3-5$ & 5 & $2-5$ & 3 & $2-3$ & $1-8$ & $2-5$ & $1-4$ \\
\hline $15 \%$ & - & + & - & + & + & + & + & - & - & + & + & + & + & - & + & + & - \\
\hline $\begin{array}{l}\text { Temperature } \\
\text { optimum }\left({ }^{\circ} \mathrm{C}\right)\end{array}$ & $30-40$ & $20-22$ & $30-40$ & 32 & 30 & 32 & $30-35$ & $20-22$ & 37 & $25-30$ & $37-40$ & $30-35$ & 37 & $30-37$ & $30-40$ & $30-35$ & $\begin{array}{r}30- \\
35\end{array}$ \\
\hline \multicolumn{18}{|l|}{ Growth at: } \\
\hline $4{ }^{\circ} \mathrm{C}$ & + & + & - & + & + & - & + & + & - & + & - & - & - & + & - & - & - \\
\hline $40{ }^{\circ} \mathrm{C}$ & + & - & + & + & + & + & + & - & + & + & + & + & + & + & + & + & + \\
\hline $45^{\circ} \mathrm{C}$ & + & - & + & + & + & - & - & - & + & + & + & - & + & - & - & - & - \\
\hline Optimum pH & 8 & ND & ND & $\mathrm{ND}$ & ND & $\mathrm{ND}$ & ND & ND & $8-9$ & ND & $7.5-8.0$ & $7-8$ & $8-9$ & $7-8$ & $8-9$ & $7-8$ & 8 \\
\hline Growth at $\mathrm{pH} 6$ & - & + & + & + & ND & + & + & + & - & + & + & + & - & + & - & + & $\mathrm{ND}$ \\
\hline \multicolumn{18}{|l|}{ Hydrolysis of: } \\
\hline Aesculin & - & - & - & + & - & + & + & - & - & + & - & - & - & - & ND & - & + \\
\hline Casein & - & ND & ND & + & ND & + & ND & ND & + & - & - & - & + & - & - & - & - \\
\hline Tween 80 & - & - & + & + & + & + & + & - & + & + & - & - & + & + & + & - & + \\
\hline \multicolumn{18}{|l|}{ Enzymes } \\
\hline DNase & + & + & + & + & + & + & + & + & + & + & + & + & + & + & + & - & + \\
\hline Gelatinase & + & + & + & + & + & + & + & + & + & + & + & + & + & - & + & + & + \\
\hline Catalase & + & + & + & + & + & + & + & + & + & + & + & + & + & + & - & + & + \\
\hline $\mathrm{H}_{2} \mathrm{~S}$ production & - & ND & + & + & ND & + & ND & ND & + & + & ND & - & - & ND & - & - & - \\
\hline Nitrate reduction & + & + & - & - & - & - & + & - & - & + & - & - & - & + & - & - & + \\
\hline \multicolumn{18}{|l|}{ Acid production from: } \\
\hline D-Arabinose & - & - & - & - & - & - & - & ND & - & - & + & - & ND & - & - & - & - \\
\hline D-Xylose & - & - & - & - & - & - & - & ND & - & - & + & - & $\mathrm{ND}$ & - & - & - & - \\
\hline \multicolumn{18}{|l|}{ API ZYM } \\
\hline $\begin{array}{l}\text { Alkaline } \\
\text { phosphatase }\end{array}$ & - & + & + & + & + & + & + & + & + & + & + & + & + & + & ND & + & + \\
\hline Esterase (C4) & - & + & + & + & + & + & + & + & + & + & + & + & + & + & ND & + & + \\
\hline Esterase lipase (C8) & - & + & + & + & + & + & + & + & + & + & + & + & + & + & ND & + & + \\
\hline Lipase (C14) & - & - & - & - & - & - & - & - & + & - & - & + & + & - & + & + & + \\
\hline Leucine arylamidase & - & + & + & + & + & + & + & + & + & + & + & + & + & + & ND & + & + \\
\hline Valine arylamidase & + & - & + & + & - & - & - & - & + & + & - & + & + & - & ND & + & + \\
\hline Cystine arylamidase & + & - & + & - & - & - & - & - & + & + & - & + & + & - & ND & + & + \\
\hline Trypsin & + & - & - & - & - & - & - & - & + & + & + & + & + & + & $\mathrm{ND}$ & + & + \\
\hline$\alpha$-Chymotrypsin & + & - & + & + & - & + & - & + & + & + & + & + & + & + & ND & + & + \\
\hline Acid phosphatase & + & + & + & $\mathrm{ND}$ & + & $\mathrm{ND}$ & + & + & + & + & + & + & + & - & ND & + & + \\
\hline \multicolumn{18}{|l|}{ Fatty acids (\%) } \\
\hline iso- $\mathrm{C}_{13: 0}$ & - & 1.4 & - & - & 1.8 & 1.4 & - & 1.6 & 2.2 & 1.7 & 1.0 & 1.3 & 1.6 & 1.6 & 3.2 & 1.7 & 4.6 \\
\hline iso- $\mathrm{C}_{13: 0} 3-\mathrm{OH}$ & - & 3.7 & 2.9 & 3.2 & 3.9 & 3.5 & 3.3 & 4.7 & 5.2 & 3.8 & 2.5 & 3.3 & 5.0 & 5.0 & 4.0 & 4.0 & 3.8 \\
\hline iso- $\mathrm{C}_{15: 0}$ & 20.5 & 22.2 & 33.4 & 26 & 28.2 & 21.5 & 24.6 & 30.5 & 22.9 & 21.9 & 16.7 & 17.0 & 26.8 & 34.1 & 28.4 & 21.4 & 37.8 \\
\hline iso- $\mathrm{C}_{15: 0} 3-\mathrm{OH}$ & 2.2 & - & - & - & - & - & - & - & - & - & - & - & - & - & - & - & - \\
\hline iso- $\mathrm{C}_{17: 0}$ & 26.5 & 11.4 & 13.3 & 10.2 & 13.5 & 14.4 & 12.4 & 12.6 & 23.1 & 8.6 & 15.3 & 18.2 & 15.4 & 19.9 & 11.6 & 21.0 & 14.4 \\
\hline Summed feature $9^{\star}$ & 25.9 & 13.4 & 8.2 & 6.6 & 11.3 & 16.1 & 10.1 & 5.2 & 12.5 & 10.4 & 10.2 & 16.6 & 11.6 & 11.8 & 11.4 & 15.7 & 8.3 \\
\hline \multicolumn{18}{|c|}{ Quinones } \\
\hline Major & Q-8 & Q-8 & Q-8 & Q-8 & Q-8 & Q-8 & Q-8 & Q-8 & Q-8 & Q-8 & Q-8 & Q-8 & Q-8 & Q-8 & Q-8 & Q-8 & Q-8 \\
\hline
\end{tabular}


Table 2. cont.

\begin{tabular}{|c|c|c|c|c|c|c|c|c|c|c|c|c|c|c|c|c|c|}
\hline Characteristic & 1 & 2 & 3 & 4 & 5 & 6 & 7 & 8 & 9 & 10 & 11 & 12 & 13 & 14 & 15 & 16 & 17 \\
\hline Minor & Q-9 & $\mathrm{ND}$ & ND & $\mathrm{ND}$ & ND & ND & $\mathrm{ND}$ & $\mathrm{ND}$ & ND & ND & $\mathrm{ND}$ & Q-7 & $\mathrm{ND}$ & $\mathrm{ND}$ & ND & Q-7 & ND \\
\hline $\begin{array}{l}\text { DNA G }+\mathrm{C} \text { content } \\
(\mathrm{mol} \%)\end{array}$ & 51.5 & 50.4 & 49.7 & 46.0 & 47.4 & 48.7 & 45.0 & 48.0 & 45.5 & 45.1 & 51.6 & 46.6 & 45.2 & 53.9 & 50.0 & 46.9 & 49.3 \\
\hline
\end{tabular}

*Summed features represent two or three fatty acids that cannot be separated by the Microbial Identification System. Summed feature 9 consisted of iso- $\mathrm{C}_{17: 1} \omega 9 c$ and/or 10-methyl $\mathrm{C}_{16: 0}$.

D-fructose, D-galactose, D-glucose, myo-inositol, lactose, maltose, D-mannitol, D-mannose, melezitose, melibiose, raffinose, D-ribose, D-sorbitol, sucrose, trehalose and Dxylose). No growth was observed in CM media, which contain glucose or other carbohydrates as sole carbon and energy sources, although these media have been shown to support the growth of various other marine bacteria (Shieh et al., 2003, 2004). Endospores were not found. Neither sporulation nor endospore-like structures were ever observed by phase-contrast microscopy and spore staining. Poly- $\beta$ hydroxybutyrate-like granules were not observed. Strain $\mathrm{AIT1}^{\mathrm{T}}$ was susceptible to ( $\mu \mathrm{g}$ per disc, unless otherwise stated) carbenicillin (100), cephalothin (30), chloramphenicol (30), colistin (10), erythromycin (15), gentamicin (10), nalidixic acid (30), novobiocin (30), penicillin $\mathrm{G}(10 \mathrm{U})$, polymyxin B (300 U) and tetracycline (30), intermediately susceptible to ampicillin (10), kanamycin (30), neomycin (30) and streptomycin (10), and resistant to oxacillin (1) and vancomycin (30). The negative reactions for alkaline phosphatase, esterase (C4), esterase lipase (C8) and leucine arylamidase with the API ZYM tests enabled strain $\mathrm{AIT1}^{\mathrm{T}}$ to be distinguished from the recognized members of the family Idiomarinaceae for which comparative data were available. Additional characteristics useful for distinguishing strain $\mathrm{AIT1}^{\mathrm{T}}$ are listed in Table 2.

On the basis of phylogenetic, chemotaxonomic and physiological data, strain $\mathrm{AIT} 1^{\mathrm{T}}$ should be classified as a representative of a novel species in a new genus in the family Idiomarinaceae for which the name Aliidiomarina taiwanensis gen. nov., sp. nov. is proposed.

\section{Description of Aliidiomarina gen. nov.}

Aliidiomarina (A.li.i.di.o.ma.ri'na. L. pronoun. alius other, another; N.L. n. Idiomarina a name of a bacterial genus; N.L. fem. n. Aliidiomarina the other Idiomarina).

Belongs to the family Idiomarinaceae in the class Gammaproteobacteria. Cells are heterotrophic, Gram-negative

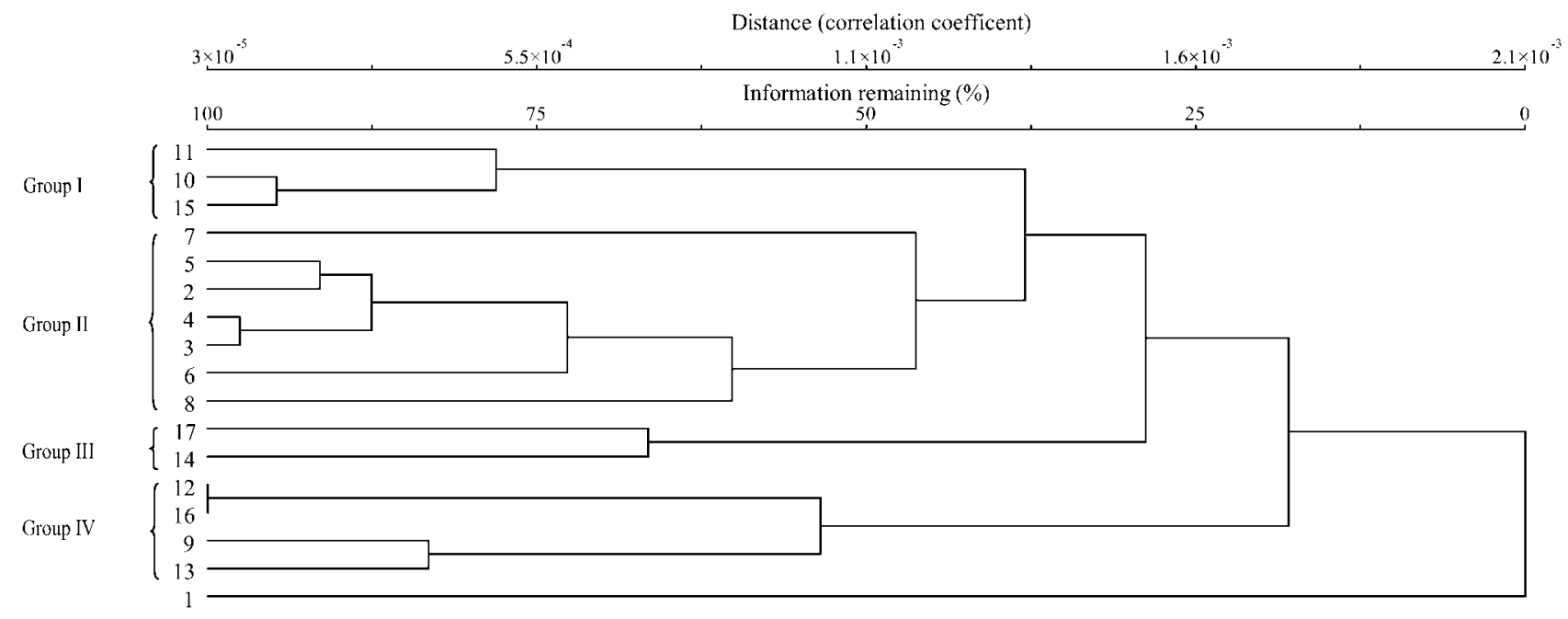

Fig. 2. Cluster analysis of cellular fatty acids of strain $A I T 1^{\top}$ and type strains of recognized species of the genus /diomarina. Strains: 1, Aliidiomarina taiwanensis sp. nov. AIT1 ${ }^{\top} ; 2$, I. abyssalis ATCC BAA-312 ${ }^{\top}$; 3, I. baltica DSM $15154^{\top}$; $4, I$. fontislapidosi DSM $16139^{\top}$; 5 , I. loihiensis DSM $15497^{\top}$; 6 , I. ramblicola DSM $16140^{\top}$; 7 , I. seosinensis JCM $12526^{\top}$; 8 , I. zobellii ATCC BAA-313 ${ }^{\top}$; 9, I. donghaiensis $908033^{\top} ; 10$, I. homiensis DSM $17923^{\top} ; 11$, I. insulisalsae CVS- $6^{\top} ; 12$, I. marina $\mathrm{PIM}^{\top}{ }^{\top} ; 13$, I. maritima $908087^{\top} ; 14$, I. salinarum CCUG $54359^{\top} ; 15$, I. sediminum LMG $24046^{\top} ; 16$, I. tainanensis PIN1 ${ }^{\top} ; 17$, I. taiwanensis $\mathrm{PIT}^{\top}$. Raw data are provided in Supplementary Table S1, available in IJSEM Online (strains are numbered according to the legend). 
rods and motile by means of a single polar flagellum. Chemo-organotrophic and capable of respiratory, but not fermentative, metabolism. Mesophilic and halophilic. Oxidase- and catalase-positive. The major fatty acids are iso-branched and include iso- $\mathrm{C}_{17: 0}$, summed feature 9 (comprising iso- $\mathrm{C}_{17: 1} \omega 9 \mathrm{c}$ and/or 10-methyl $\mathrm{C}_{16: 0}$ ) and iso- $\mathrm{C}_{15: 0}$. The minor cellular fatty acids include iso- $\mathrm{C}_{15: 0}$ 3-OH. $\mathrm{C}_{13: 0}$ and iso- $\mathrm{C}_{13: 0} 3-\mathrm{OH}$ are not detected. Q-8 is the major isoprenoid quinone and Q-9 is a minor quinone. The major polar lipids are diphosphatidylglycerol, phosphatidylglycerol and phosphatidylethanolamine. The genus-specific nucleotide positions in the $16 \mathrm{~S}$ rRNA gene (E. coli K12 numbering) include positions 240 (A), $286(\mathrm{~T}), 762(\mathrm{~A}), 811(\mathrm{~T}), 1336(\mathrm{~A})$ and $1439(\mathrm{G})$. The DNA G + C content is approximately $51-52 \mathrm{~mol} \%$. The type species is Aliidiomarina taiwanensis.

\section{Description of Aliidiomarina taiwanensis sp. nov.}

Aliidiomarina taiwanensis (tai.wan.en'sis. N.L. fem. adj. taiwanensis pertaining to Taiwan, where the type strain was isolated).

Has the following characteristics in addition to those given for the genus. Cells are approximately $1.5-2.8 \mu \mathrm{m}$ long and $0.5-0.8 \mu \mathrm{m}$ wide. After incubation on PY agar at $30{ }^{\circ} \mathrm{C}$ for 7 days, colonies are approximately $4-6 \mathrm{~mm}$ in diameter, light brown, circular, convex and non-luminescent, with entire edges. Endospores are absent. Poly- $\beta$-hydroxybutyrate is not accumulated. Nitrate is reduced to nitrite, but not to nitrous oxide or nitrogen. $\mathrm{NaCl}$ is required for growth: grows with $0.5-10 \% \mathrm{NaCl}$ (optimum 1.5-5.0\%), but not with 0 or $12.5 \% \mathrm{NaCl}$. Grows at $4-45{ }^{\circ} \mathrm{C}$ (optimum $30-40{ }^{\circ} \mathrm{C}$ ), but not at $50{ }^{\circ} \mathrm{C}$, and at $\mathrm{pH} 7-9$, but not at $\mathrm{pH} 6$ or 10. Arginine dihydrolase, lysine decarboxylase and ornithine decarboxylase are absent. Indole is produced. $\mathrm{H}_{2} \mathrm{~S}$ is not produced from thiosulphate. DNA and gelatin are hydrolysed, but aesculin, agar, casein, starch, Tween 80 and urea are not. With API ZYM, positive for acid phosphatase, valine arylamidase, cystine arylamidase, $\alpha$-chymotrypsin, naphthol-phosphohydrolase and trypsin. With API $50 \mathrm{CH}$, oxidizes $\mathrm{N}$-acetylglucosamine, starch, L-arabinose, erythritol, D-fructose, L-fucose, D-galactose, D-glucose, glycerol, glycogen, maltose, Dmannitol, D-mannose, potassium gluconate, D-ribose, sucrose and trehalose. With GN2 MicroPlates, oxidizes acetic acid, $\mathrm{N}$-acetyl-D-galactosamine, $\mathrm{N}$-acetyl-D-glucosamine, L-asparagine, L-aspartic acid, bromosuccinic acid, dextrin, D-fructose, L-fucose, $\alpha$-D-glucose, D-glucose 6phosphate, D-gluconic acid, D-glucosaminic acid, L-glutamic acid, glycogen, glycyl L-aspartic acid, L-histidine, $p$ hydroxyphenylacetic acid, inosine, DL-lactic acid, maltose, D-mannitol, D-mannose, D-psicose, pyruvic acid methyl ester, L-serine, sucrose, trehalose, thymidine, turanose and uridine.

The type strain, AIT1 $^{\mathrm{T}}\left(=\mathrm{JCM} 16052^{\mathrm{T}}=\mathrm{BCRC} 80035^{\mathrm{T}}\right.$ $=$ NCCB $100321^{\mathrm{T}}$ ), was isolated from shallow coastal seawater of Bitou Harbour, New Taipei City, Taiwan. The DNA G + C content of the type strain is $51.5 \mathrm{~mol} \%$.

\section{Acknowledgements}

This study was supported by the National Science Council, Taiwan (grant numbers NSC96-2621-B-002-009-MY2, NSC97-2221-E-426003 and NSC98-2313-B-002-057-MY2).

\section{References}

Bowman, J. P. \& McMeekin, T. A. (2005). Genus I. Alteromonas Baumann, Baumann, Mandel and Allen 1972, 418, emend. Gauthier, Gauthier and Christen 1995a, 760. In Bergey's Manual of Systematic Bacteriology, 2nd edn, vol. 2, pp. 444-447. Edited by D. J. Brenner, N. R. Krieg, J. T. Staley \& G. M. Garrity. New York: Springer.

Brettar, I., Christen, R. \& Höfle, M. G. (2003). Idiomarina baltica sp. nov., a marine bacterium with a high optimum growth temperature isolated from surface water of the central Baltic Sea. Int J Syst Evol Microbiol 53, 407-413.

Choi, D. H. \& Cho, B. C. (2005). Idiomarina seosinensis sp. nov., isolated from hypersaline water of a solar saltern in Korea. Int J Syst Evol Microbiol 55, 379-383.

Donachie, S. P., Hou, S., Gregory, T. S., Malahoff, A. \& Alam, M. (2003). Idiomarina loihiensis sp. nov., a halophilic $\gamma$-Proteobacterium from the Lō'ihi submarine volcano, Hawai'i. Int J Syst Evol Microbiol 53, 1873-1879.

Hu, Z.-Y. \& Li, Y. (2007). Pseudidiomarina sediminum sp. nov., a marine bacterium isolated from coastal sediments of Luoyuan Bay in China. Int J Syst Evol Microbiol 57, 2572-2577.

Ivanova, E. P., Romanenko, L. A., Chun, J., Matte, M. H., Matte, G. R., Mikhailov, V. V., Svetashev, V. I., Huq, A., Maugel, T. \& Colwell, R. R. (2000). Idiomarina gen. nov., comprising novel indigenous deep-sea bacteria from the Pacific Ocean, including descriptions of two species, Idiomarina abyssalis sp. nov. and Idiomarina zobellii sp. nov. Int J Syst Evol Microbiol 50, 901-907.

Ivanova, E. P., Flavier, S. \& Christen, R. (2004). Phylogenetic relationships among marine Alteromonas-like proteobacteria: emended description of the family Alteromonadaceae and proposal of Pseudoalteromonadaceae fam. nov., Colwelliaceae fam. nov., Shewanellaceae fam. nov., Moritellaceae fam. nov., Ferrimonadaceae fam. nov., Idiomarinaceae fam. nov. and Psychromonadaceae fam. nov. Int J Syst Evol Microbiol 54, 1773-1788.

Jean, W. D., Shieh, W. Y. \& Chiu, H.-H. (2006). Pseudidiomarina taiwanensis gen. nov., sp. nov., a marine bacterium isolated from shallow coastal water of An-Ping Harbour, Taiwan, and emended description of the family Idiomarinaceae. Int J Syst Evol Microbiol 56, 899-905.

Jean, W. D., Leu, T.-Y., Lee, C.-Y., Chu, T.-J., Lin, S. Y. \& Shieh, W. Y. (2009). Pseudidiomarina marina sp. nov. and Pseudidiomarina tainanensis sp. nov. and reclassification of Idiomarina homiensis and Idiomarina salinarum as Pseudidiomarina homiensis comb. nov. and Pseudidiomarina salinarum comb. nov., respectively. Int J Syst Evol Microbiol 59, 53-59.

Kwon, S.-W., Kim, B.-Y., Weon, H.-Y., Baek, Y.-K., Koo, B.-S. \& Go, S.-J. (2006). Idiomarina homiensis sp. nov., isolated from seashore sand in Korea. Int J Syst Evol Microbiol 56, 2229-2233.

Lin, Y.-T. \& Shieh, W. Y. (2006). Zobellella denitrificans gen. nov., sp. nov. and Zobellella taiwanensis sp. nov., denitrifying bacteria capable of fermentative metabolism. Int J Syst Evol Microbiol 56, 1209-1215. 
Martínez-Cánovas, M. J., Béjar, V., Martínez-Checa, F., Páez, R. \& Quesada, E. (2004). Idiomarina fontislapidosi sp. nov. and Idiomarina ramblicola sp. nov., isolated from inland hypersaline habitats in Spain. Int J Syst Evol Microbiol 54, 1793-1797.

McCune, B. \& Mefford, M. J. (1999). PC-ORD for Windows. Multivariate Analysis of Ecological Data, version 5.10. Glenedon Beach, OR: MjM Software.

Sasser, M. (1990). Identification of bacteria by gas chromatography of cellular fatty acids, MIDI Technical Note 101. Newark, DE: MIDI Inc.

Shieh, W. Y., Chen, A. L. \& Chiu, H. H. (2000). Vibrio aerogenes sp. nov., a facultatively anaerobic marine bacterium that ferments glucose with gas production. Int J Syst Evol Microbiol 50, 321-329.

Shieh, W. Y., Jean, W. D., Lin, Y.-T. \& Tseng, M. (2003). Marinobacter lutaoensis sp. nov., a thermotolerant marine bacterium isolated from a coastal hot spring in Lutao, Taiwan. Can J Microbiol 49, 244-252.

Shieh, W. Y., Lin, Y.-T. \& Jean, W. D. (2004). Pseudovibrio denitrificans gen. nov., sp. nov., a marine, facultatively anaerobic, fermentative bacterium capable of denitrification. Int J Syst Evol Microbiol 54, 2307-2312.

Shieh, W. Y., Liu, T. Y., Lin, S. Y., Jean, W. D. \& Chen, J.-S. (2008). Simiduia agarivorans gen. nov., sp. nov., a marine, agarolytic bacterium isolated from shallow coastal water from Keelung, Taiwan. Int J Syst Evol Microbiol 58, 895-900.

Taborda, M., Antunes, A., Tiago, I., Verissimo, A., Nobre, M. F. \& da Costa, M. S. (2009). Description of Idiomarina insulisalsae sp. nov., isolated from the soil of a sea salt evaporation pond, proposal to transfer the species of the genus Pseudidiomarina to the genus Idiomarina and emended description of the genus Idiomarina. Syst Appl Microbiol 32, 371-378.

Wu, Y.-H., Shen, Y.-Q., Xu, X.-W., Wang, C.-S., Oren, A. \& Wu, M. (2009). Pseudidiomarina donghaiensis sp. nov. and Pseudidiomarina maritima sp. nov., isolated from the East China Sea. Int J Syst Evol Microbiol 59, 1321-1325.

Yoon, J.-H., Jung, S.-Y., Jung, Y.-T. \& Oh, T.-K. (2007). Idiomarina salinarum sp. nov., isolated from a marine solar saltern in Korea. Int $J$ Syst Evol Microbiol 57, 2503-2506. 